\title{
Artur Arkit
}

e-mail: arturarkit@interia.pl

Maciej Puchała** (D) https://orcid.org/0000-0001-7723-1913

e-mail: m.puchala@wp.pl

\section{Analiza i ocena obsługi klienta w firmie kurierskiej XYZ}

https://doi.org/10.25312/2391-5129.31/2020_08aamp

\begin{abstract}
Logistyczna obsługa klienta jest jednym z najważniejszych narzędzi do budowania konkurencyjności firmy na rynku. W pracy oceniono skuteczność obsługi klienta firmy XYZ ukierunkowanej głównie na terminowość bieżących usług i liczbę reklamacji. Charakterystyka branży kurierskiej w Polsce, ocena kooperacji z polskimi firmami TSL oraz wyniki badań pokazały wpływ branży na polską firmę XYZ. Dane zebrane podczas pracy w firmie XYZ pozwoliły uzyskać odpowiedź na pytania dotyczące wskaźników logistycznej obsługi klienta i terminowości usług. Przedstawione dane i wskaźniki opierają się na informacjach uzyskanych $w$ trakcie pracy $w$ firmie i gromadzeniu danych statystycznych.
\end{abstract}

Słowa kluczowe: usługa kurierska, obsługa klienta, jakość usługi

\section{Wprowadzenie}

Rynek kurierski w ciągu ostatnich dwóch dekad rozwinął się bardzo pomimo kryzysu gospodarczego, który pojawił się pod koniec XX wieku. Popyt na obsługę przesyłek kurierskich przy pomocy zewnętrznych firm logistycznych posiadających

* Inż. Artur Arkit - absolwent studiów inżynierskich na Akademii Humanistyczno-Ekonomicznej w Łodzi, Wydział Techniki i Informatyki, kierunek transport, autor pracy dyplomowej Analiza i ocena obstugi klienta w firmie kurierskiej XYZ (maszynopis niepublikowany).

** Dr inż. Maciej Puchała - adiunkt w Katedrze Systemów Transportu na Wydziale Techniki i Informatyki, Akademia Humanistyczno-Ekonomiczna w Łodzi, promotor pracy dyplomowej A. Arkita Analiza i ocena obstugi klienta w firmie kurierskiej XYZ. 
doświadczenie oraz zasoby sprzętowe sprawił, że rynek usług kurierskich stał się jedną z najszybciej rozwijających się branż w kraju, a zapotrzebowanie na obsługę klienta indywidualnego okazało się siłą napędową branży kurierskiej nie tylko w Polsce, ale i na świecie.

Celem artykułu jest analiza i ocena obsługi klienta na przykładzie firmy kurierskiej mającej swój oddział pod Łodzią. Doświadczenie zdobyte w środowisku kurierskim, w tym zetknięcie się z różnymi opiniami prezentowanymi przez osoby z branży oraz klientami, z którymi autor (Arkit, 2020) miał styczność, pozwala sformułować wniosek, że analiza jakości obsługi klienta jest najczęściej pomijana, a ocena odnosi się z reguły tylko do produktów w ujęciu materialnym. Bardzo istotnym elementem z punktu widzenia autorów jest wpływ obsługi klienta na prowadzenie firmy oraz jej odbiór przez obsługiwanych klientów.

\section{Rynek usług kurierskich. Wybrane informacje}

$\mathrm{Na}$ rynku polskim usługi kurierskie realizowane są przez wiele przedsiębiorstw z branży. Różnica pomiędzy nimi dotyczy poziomu oferowanych usług oraz zasięgu, a co za tym idzie - ceny.

W niniejszej pracy zostały przeanalizowane dane z okresu od roku 2016 do roku 2018. Z tychże danych można wywnioskować, że w branży kurierskiej z roku na rok odnotowuje się tendencję wzrostową. Zapotrzebowanie na usługi tego rodzaju będzie rosnąć, zarówno w odniesieniu do przesyłek krajowych, jak i zagranicznych.

W 2018 roku przetransportowano o ponad 102 mln paczek więcej niż w roku 2016. Należy zwrócić szczególną uwagę na fakt, że przesyłki krajowe (349,8 mln paczek) cieszą się większą popularnością niż przesyłki zagraniczne (37,9 mln paczek).

Branża kurierska w Polsce proponuje trzy rodzaje przesyłek, określanych jako: B2B, B2C i C2X. Pierwsza z nich, B2B (business to business), odnosi się do zamówień pomiędzy dwoma lub więcej podmiotami gospodarczymi. W skład całej transakcji między dwoma podmiotami wchodzi przygotowanie oferty i zamówienie, ich potwierdzenie, dokonanie płatności po wcześniejszym ustaleniu jej formy, realizacja zamówienia, obsługa klienta związana z dokumentacją przesyłki, badania rynku, marketing. Drugim rodzajem przesyłek jest forma B2C (business to consumer), która oznacza zawarcie transakcji pomiędzy przedsiębiorstwem a klientem indywidualnym. Zasada działania tych usług jest zbliżona do usługi B2B. Należy nadmienić, że najczęstszą formą składania zamówienia jest strona internetowa, często skonstruowana bardzo intuicyjnie, aby złożenie zamówienia nie sprawiło kłopotu zamawiającemu usługę kurierską. Trzecim rodzajem przesyłek kurierskich jest przesyłka C2X (consumer to business/consumer), która charakteryzuje się relacją pomiędzy wszystkimi podmiotami, zarówno gospodarczymi, jak i indywidualnymi. 
W wyniku analizy zebranych danych można śmiało postawić wniosek, że wśród wyżej wymienionych rodzajów przesyłek prym zdecydowanie wiedzie przesyłka rodzaju B2B (ponad 55\%), co prezentuje rysunek 1.

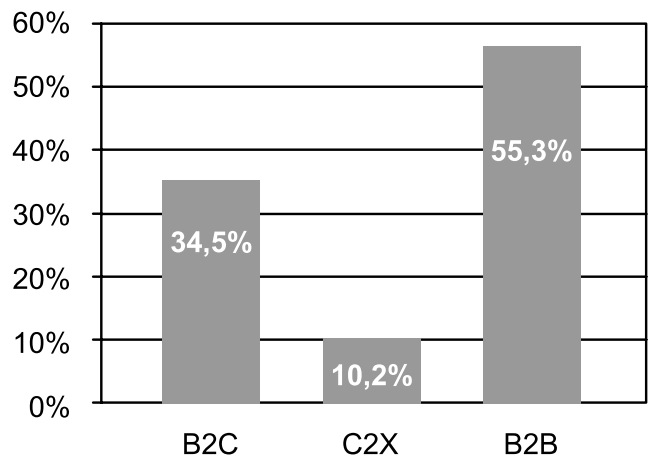

Rysunek 1. Przesyłki w obrocie krajowym i zagranicznym w 2018 roku

Źródło: PWC (2019), Perspektywy wzrostu rynku przesyłek kurierskich, ekspresowych i paczkowych (KEP) w Polsce do $2018 r$.

Badania przeprowadzone wśród klientów w 2018 roku wykazały, że rynek usług kurierskich w Polsce ma trzech liderów: DHL, DPD i UPS. Opinia klientów serwisu logistycznego pozwoliła na wyłonienie ośmiu najbardziej profesjonalnych firm kurierskich w Polsce (tab. 1). W przeprowadzonym badaniu ankietowane osoby deklarowały swoje preferencje w doborze firmy kurierskiej. W trakcie analizy danych badania stwierdzono, że poziom zadowolenia klientów z usług firm kurierskich jest bardzo zbliżony. Najważniejszymi czynnikami branymi pod uwagę przy ocenie usług kurierskich były: terminowość, szybkość i cena za dostarczenie przesyłki.

Tabela 1. Średnia ocena usług kurierskich

\begin{tabular}{|c|l|c|c|}
\hline Pozycja & Nazwa firmy & Liczba opinii & Średnia ocena \\
\hline 1 & DHL & 92872 & 9,2 \\
\hline 2 & DPD & 120524 & 9,1 \\
\hline 3 & UPS & 78780 & 9,1 \\
\hline 4 & GLS & 39242 & 8,8 \\
\hline 5 & FEDEX & 6728 & 8,6 \\
\hline 6 & TNT & 457 & 8,4 \\
\hline 7 & Poczta & 40038 & 8,4 \\
\hline 8 & Pocztex & 14800 & 8,2 \\
\hline
\end{tabular}

Źródło: PWC (2019), Perspektywy wzrostu rynku przesyłek kurierskich, ekspresowych i paczkowych (KEP) w Polsce do 2018 r. 
Nowe podmioty pojawiające się na rynku mogą szybko się rozwijać z powodu niewielkich barier, ale potencjał rozwojowy zależy od dziedziny, w jakiej one działają. Firmy już istniejące mają ogromny wachlarz możliwości rozwoju, jednak kluczowym czynnikiem decydującym o sukcesie jest ocena konkurencyjności, zawierająca kilka pozycji w swojej strukturze - dzięki niej można ukazać pozycję podmiotu na rynku.

Definicję otoczenia konkurencyjnego dowolnego podmiotu można znaleźć w wielu pracach. Przez podmiot możemy rozumieć grupę podmiotów współpracujących bądź konkurujących ze sobą, a ich wspólnym celem jest spełnienie oczekiwań potencjalnych klientów. Podmioty współpracujące ze sobą mogą przynieść wymierne rezultaty, wzajemnie się wspierając i działając wspólnie, natomiast utrudnianie sobie działalności nawzajem może skutkować problemami w utrzymaniu się na rynku. Patrząc jednak z perspektywy podmiotu, każdy z nich decyduje o swojej przyszłości i sam tworzy swoje otoczenie konkurencyjne. W skład otoczenia konkurencyjnego podmiotu wchodzą:

- klienci,

- dostawcy,

- konkurencja,

- izby branżowe,

- instytuty naukowe,

- instytucje polityczne,

- stowarzyszenia.

Stworzenie analizy do określenia potencjału rozwojowego jest możliwe tylko wtedy, kiedy zdobędziemy najistotniejsze informacje pomagające naznaczyć potencjał rozwojowy rynku. Takimi podstawowymi informacjami są dane określające możliwości rozwojowe w sektorze, jego atrakcyjność, dostrzeżenie zagrożeń i możliwości rynkowych oraz znalezienie i zagospodarowanie rynków, które nie są jeszcze zdominowane przez konkurencję.

Rynek kurierski oraz podobne podmioty działające w Polsce wykonały ogrom pracy, aby ta branża dynamicznie wpłynęła na rozwój gospodarczy w kraju, chociaż funkcjonuje stosunkowo krótko. Ostatnie 4 lata były dla niej przełomowe. Dynamikę rozwoju sektora kurierskiego, przekładającą się na wartość firm, ukazuje rysunek 2. 


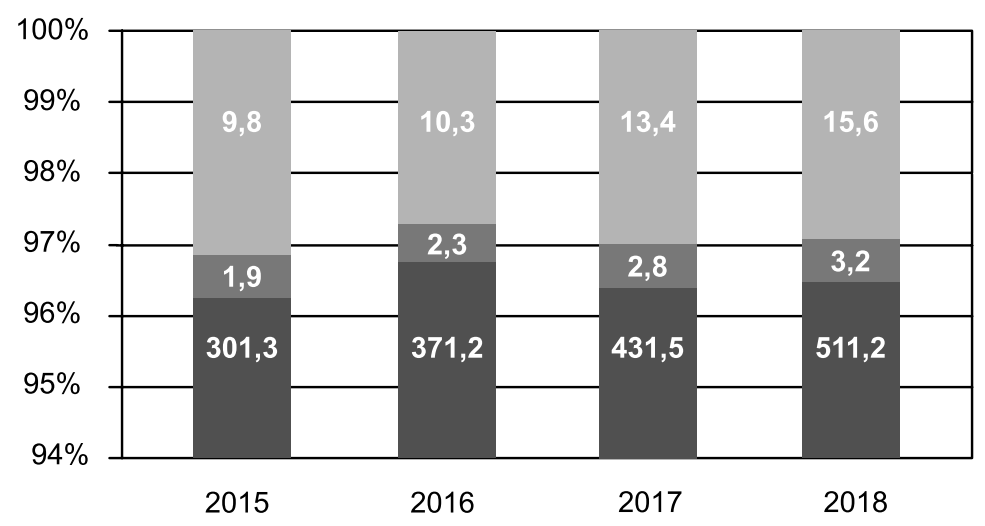

\section{Zagranica - ekonomiczna Zagranica-ekspresowa $\square$ Kraj}

Rysunek 2. Wolumen rynku KEP w latach 2015-2018 (w mln paczek)

Źródło: PWC (2019), Perspektywy wzrostu rynku przesyłek kurierskich, ekspresowych i paczkowych (KEP) w Polsce do 2018 r.

Rysunek 2 obrazuje wyraźny wzrost zapotrzebowania na usługi kurierskie, co ma odzwierciedlenie w zdecydowanym rozwoju oraz zwiększeniu wartości podmiotów w tym sektorze. Dynamika wzrostu wartości runku została przedstawiona na rysunku 3.

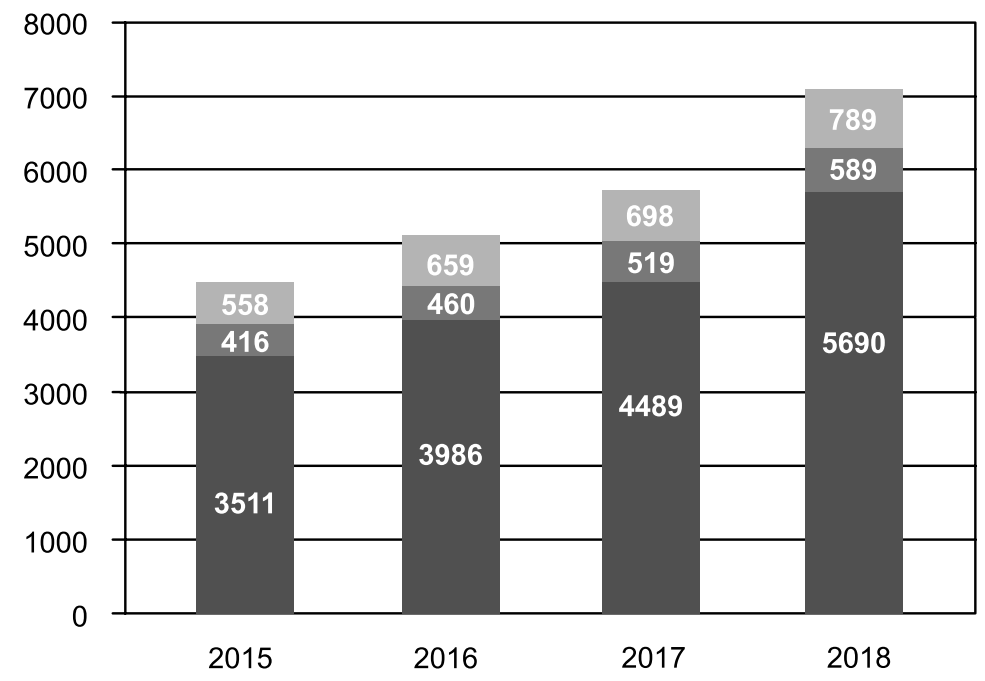

\section{Zagranica - ekonomiczna \\ Zagranica - ekspresowa \\ Kraj \\ Rysunek 3. Rynek KEP w latach 2015-2018 (w mln zł)}

Źródło: PWC (2019), Perspektywy wzrostu rynku przesyłek kurierskich, ekspresowych i paczkowych (KEP) w Polsce do 2018 r. 
Odnosząc się do rysunku 3, można wywnioskować, że branża usług kurierskich ma nie tylko możliwość rozwoju już istniejących podmiotów, ale również daje szansę zaistnienia nowym firmom na rynku KEP.

\section{Źródła przewagi konkurencyjnej firmy XYZ na rynku}

Osiągnięcie sukcesu w działalności jest możliwe dzięki umiejętnemu zarządzaniu zasobami ludzkimi. Jednym z kluczowych czynników w działalności podmiotu jest jakość personelu oraz jego umiejętność rozwiązywania problemów występujących w procesie przedtransakcyjnym i potransakcyjnym. W literaturze na temat marketingu można znaleźć opinię, iż działalność usługowa różni się od działalności produkcyjnej właśnie tym, że czynnik ludzki ma większy wpływ na uzyskanie przewagi konkurencyjnej w stosunku do konkurencji.

Celem każdego podmiotu jest utrzymanie jak najwyższych standardów w procesie komunikacji marketingowej. Na przełomie ostatnich kilkunastu lat zaczęło dominować pojęcie komunikacji bezpośredniej, skierowanej do konkretnego klienta. Kompetencje, wyszkolenie oraz zaangażowanie personelu w tego typu komunikację są bardzo istotnym elementem działalności marketingowej firmy. Posiadanie kadry, która oprócz tego, że zna świetnie potrzeby swoich klientów, ma zdolności przedstawienia oferty w atrakcyjny sposób, zwiększając obrót firmy i efektywnie kończąc całą transakcję, ma duże znaczenie. Wkład personelu oraz jego olbrzymią rolę podkreśla I. Dembińska-Cyran I. (2004: 21), przedstawiając koncepcję marketingu mix, uwzględniającego wagę personelu na rynku usług.

Cechy, jakie powinni posiadać pracownicy mający bezpośredni kontakt z klientem, to:

- otwartość,

- respektowanie zdania klienta,

- aktywność w słuchaniu swoich klientów,

- umiejętność wyjaśniania wątpliwości klientów (Boguszewicz-Kreft, 2005: 298).

Zaangażowanie personelu w branży usługowej odzwierciedla opinię klienta o samym produkcie i chociaż usługi mają charakter niematerialny, potrzebna jest interakcja z klientem, dzięki której pracownik będzie częścią oferty firmy. Dlatego tak ważne jest zaangażowanie i realizacja zadań powierzonych personelowi. Biorąc pod uwagę teorie odnoszące się do marketingu usług, jak również wielowątkowość ról odgrywanych przez personel, nie można pominąć znaczenia personelu, który ma bezpośredni kontakt z klientem, jako istotnego elementu struktury firmy.

Zadania powierzone personelowi kontaktującemu się bezpośrednio z klientem można ująć w kilku przykładach:

- orientacja ukierunkowana na to, by zrozumieć system wartości, jaki reprezentuje dany klient; krytycznym elementem w tym przypadku staje się rozpoznanie i umiejętność jednoczesnego wskazania rozwiązań, których oczekuje klient; 
- służebna postawa personelu w stosunku do klienta, będąca wyrazem poświęcenia entuzjazmu i doświadczenia kadry na rzecz realizacji obsługi klienta;

- podnoszenie kwalifikacji zawodowych personelu, mające na celu lepszą identyfikację potrzeb klienta oraz rozwijanie umiejętności znajdowania pożądanych rozwiązań (Styś, 2001: 26-27).

Znaczenie personelu w logistycznej obsłudze klienta w aspekcie zachowania w organizacji niewiele różni się od obsługi klienta w marketingu. W zakresie świadczenia logistycznej obsługi klienta wymagane są również pewne cechy osobowościowe, aby poziom usług był wciąż w centrum uwagi firmy.

W literaturze podkreśla się fakt, że w przypadku usług personel stanowi substytut materialnego produktu, stąd też na rynku o wysokim stopniu konkurencyjności znaczenie personelu, a także samego procesu i świadectw materialnych związanych z otoczeniem klienta to elementy wpływające na zachowanie się klienta. Z drugiej strony kompetencje personelu wpływają pośrednio na ocenę samego produktu.

Zastosowanie procedur w firmie kurierskiej XYZ charakteryzuje się przyjęciem identycznego modelu, który jest stosowany w głównej siedzibie w Stanach Zjednoczonych. Ujednolicenie procedur powoduje, że procedury usług oferowanych przez firmę są takie same i klienci w dowolnej części świata otrzymają bardzo podobny produkt. Zautomatyzowanie procesu obsługi klienta może odciążyć pracowników firmy, a jednocześnie umożliwia przekazywanie informacji o procesie obsługi przesyłek na każdym etapie realizowania usługi. W niedalekiej przeszłości procedura złożenia zamówienia i nadania przesyłek oparta była na obsłudze bezpośredniej z kurierem. Rozwój technologiczny spowodował ogromne zmiany w tym zakresie, polegające między innymi na tym, że aby wysłać przesyłkę kurierem, trzeba ją wprowadzić w system operacyjny firmy, a klient musi otrzymać elektroniczny list przewozowy, który zawiera wszystkie informacje na temat nadawcy i odbiorcy.

Firma obecnie unika przyjmowania jakichkolwiek zleceń bezpośrednio przez kuriera, ponieważ mogą z tego wynikać komplikacje dotyczące kontrolowania i śledzenia przesyłki do momentu wprowadzenia jej do systemu. Najprostszą formą złożenia zamówienia jest kontakt telefoniczny z biurem obsługi klienta bądź skorzystanie ze strony internetowej. Procedury złożenia zamówienia tymi dwoma kanałami pozwalają na dokładne ewidencjonowanie realizacji zlecenia i zapewniają bezpieczeństwo poprzez wprowadzenie najbardziej potrzebnych informacji do systemu. Zarówno nadanie, jak i odbiór czy dostarczenie przesyłki obejmuje określone procedury, które są przestrzegane. Związane są one z optymalizacją zadań i zaplanowaniem pracy. Kurierzy nie mają zautomatyzowanego systemu określania trasy przejazdu i sami obierają optymalną trasę w zależności od wymagań czasowych wybranych przez klienta.

Obserwując pracę oddziału, można zauważyć dwie prawidłowości, po pierwsze, dostarczenie nadanych przesyłek musi odbyć się do godziny 16.00, po tej godzinie klient nadający przesyłkę i posiadający informację zarejestrowaną w systemie po podjęciu kuriera ma prawo do reklamacji niezrealizowanej usługi. 
Drugą prawidłowością jest informacja dostarczana bezpośrednio przez kuriera przed dostarczeniem przesyłki. Oprócz systemów informatycznych wspomagających obsługę klienta, takich jak śledzenie przesyłki, wysyłanie wiadomości tekstowej z przybliżoną godziną dotarcia do klienta, sami kurierzy kontaktują się z odbiorcą w celu ustalenia godziny dostarczenia przesyłki. Procedury firmy stanowią, że kurier ma za zadanie dostarczyć przesyłkę w godzinach od 8.00 do 20.00 bez względu na to, czy jest to firma, czy osoba fizyczna. Zaznaczyć jednak trzeba, że przestrzeganie tej procedury w stosunku do osób fizycznych jest nierealne ze względu na to, że obowiązki zawodowe mogą uniemożliwić odbiór przesyłki w godzinach pracy odbiorcy. Należy zwrócić uwagę, że niektóre procedury trudno zrealizować w praktyce. $\mathrm{Z}$ relacji kurierów wynika, że zmiany proceduralne powinny uwzględnić faktyczne potrzeby związane z obsługą przesyłek w tym rejonie. Rejonizacja pracy kurierów i obsługi klienta stanowi ważny aspekt pracy w branży kurierskiej. Bardzo często kurier jest jedynym pracownikiem firmy kurierskiej, z którą klient ma kontakt bezpośredni. Oznacza to, że nadanie paczki w jego regionie będzie obsługiwane przez jedną osobę. Uważa się, że klient korzystający z usługi kurierskiej cyklicznej ma bardzo istotne znaczenie przy ustalaniu godzin odbioru bądź dostarczenia przesyłki, co ma znaczący wpływ na kształtowanie procesów logistycznych w samej firmie. Zgodnie $\mathrm{z}$ procedurami przesyłka standardowa powinna być dostarczona w ciągu 7 dni od jej wysłania. Główną niepisaną praktyką firmy jest zasada dostarczenia przesyłki do 24 godzin od jej nadania. Nie można nie zauważyć, iż jest to niezgodne z procedurami, aczkolwiek praktyka ta ma istotny wpływ na efektywność procesu i ocenę obsługi klienta. Ze względu na fakt istnienia procedury dostarczenia przesyłki do 7 dni w przypadku zgłoszenia reklamacji przez klienta z powodu niedostarczenia przesyłki następnego dnia obsługa klienta może odmówić przyjęcia reklamacji.

W tym miejscu należy wspomnieć o procedurach dotyczących przesyłek ekspresowych albo takich, na których jest wystawiona dokładna data i godzina dostarczenia przesyłki. Ze względu na trudności logistyczne oraz obsługę takiej przesyłki firma wprowadziła specjalne ceny oferowane na tego typu usługi. Osobne standardy obejmują klientów chcących przewieźć ładunki specjalne, do których potrzebny jest specjalistyczny sprzęt. Ubezpieczyciel określa w umowie, co pokrywa w wyniku powstałych uszkodzeń, dlatego firma nie przewozi żywych stworzeń, ładunków płynnych bez względu na formę ich zapakowania i zabezpieczenia. Firma nie oferuje konwoju pieniędzy ani wartościowych rzeczy, z małym wyjątkiem, dla którego usługi są świadczone na specjalnych zasadach.

Obowiązujące procedury zakładają również, że firma bądź osoba fizyczna nadająca przesyłkę ma obowiązek odpowiednio ją zabezpieczyć, aby nie uległa zniszczeniu podczas transportu. Kurier przy przyjęciu przesyłki ma obowiązek zweryfikowania zabezpieczenia przesyłki i odmowy jej przyjęcia w wypadku, kiedy jej stan nie pozwala na bezpieczne dostarczenie przesyłki do odbiorcy.

Nie ulega wątpliwości, że procedury stworzone w firmie nie są przestrzegane w całości, co wynika w dużym stopniu z tego, że trudno je przełożyć na realia istnie- 
jące w trakcie pracy kuriera i trudności w jej realizacji, jednak patrząc szerzej na zagadnienie obsługi klienta i standardy panujące w firmie, można śmiało stwierdzić, że jakość usług oferowanych przez firmę jest satysfakcjonująca. Liczba realizowanych zadań w firmie XYZ nie pozwala jednoznacznie określić poziomu obsługi klienta, niemniej wprowadzanie wielu rozwiązań w sferze informatycznej i proceduralnej powoduje, że poziom pomyłek związanych z działalnością kurierską jest niwelowany.

Rozwój technologiczny skutkuje coraz mniejszą liczbą kontaktów klientów z pracownikami, co zmniejsza możliwość popełnienia błędu, a cały ciężar przenosi na rozwiązania systemowe związane z działem IT. Przyglądając się bliżej przychodom firmy, można stanowczo stwierdzić, że największy przychód w działalności firmy generują kurierzy, tak więc obsługa klienta w przyszłości będzie zastąpiona elektronicznymi systemami obsługi.

Uważa się, że kurierzy generujący główną część przychodów firmy w przyszłości mogą być również zastąpieni przez nieustannie rozwijające się technologie. Przykładem takim może być firma Amazon, która uruchomiła system Amazon Prime Air, polegający na przejęciu pracy kurierów przez drony.

Autor zakłada, że z punktu widzenia klienta takie rozwiązanie zrewolucjonizowałoby rynek kurierski i stanowiło krok milowy w obsłudze klienta. Analizując całość obsługi klienta w firmie XYZ, można zauważyć niewielkie niesystematyczne luki we współpracy pomiędzy poszczególnymi działami. Wiążą się one przede wszystkim z nieefektywnym kanałem komunikacyjnym. Kierownictwo każdego z działów jest zlokalizowane w Warszawie, lokalni pracownicy ze względu na swoje obowiązki, kompetencje i brak płynnego przepływu informacji nie są w stanie podejmować szybkich i kluczowych decyzji, a widoczne jest to najbardziej w komunikacji pomiędzy przedstawicielami handlowymi a innymi komórkami firmy. Zaobserwowano brak ustalonych ram współpracy, a także informowania zarówno systemowego, jak i bezpośredniego o uprzywilejowanych warunkach wybranych klientów. Skutkiem takiego stanu jest pozycja kurierów, którzy pracując bezpośrednio z klientem, są narażeni na skargi, ataki werbalne. Obwiniani są za wszystkie nieprawidłowości, które nie wynikają bezpośrednio z ich błędu.

Można odnieść wrażenie, że firma XYZ nie skupia odpowiedniej uwagi na poprawie efektywności jakości obsługi klienta, dążąc jedynie do jak najszybszego zbycia klienta w jak najkrótszym czasie. Dowodem na to może być fakt, że pracownicy obsługi klienta rozliczani są z czasu rozmowy z klientem, czyli im krótszy kontakt z klientem, tym lepsza ocena pracownika obsługi klienta. Natomiast kurierzy mają za zadanie ograniczyć kontakt z odbiorcą przesyłki do minimum, nie mówiąc już o przyjęciu reklamacji, która powoduje frustrację ich samych, jak i klientów.

Ujednolicenie procedur, które zostały utworzone w Stanach Zjednoczonych, zdaniem autora może być nie do końca dobrym rozwiązaniem. Wynika to z tego, że w ujednoliceniu systemu procedur dla polskiego oddziału nie uwzględniono różnic technologicznych, logistycznych, infrastruktury, a przede wszystkim różnic 
kulturowych. Wszystkie procedury nastawione na analizę i skuteczną realizację potrzeb klientów są pomniejszane i ignorowane. Obsługa klienta, szczególnie gotówkowego, realizuje tylko jego potrzebę, bez budowania relacji, a jedynym wyjątkiem są podmioty gospodarcze, którym przedstawia się promocyjne ceny tylko i wyłącznie dlatego, że pracownik może otrzymać z tego tytułu profity przewidziane w systemie motywacyjnym firmy. Dział handlowy powinien być komórką najbardziej uprawnioną do podnoszenia standardów jakości obsługi klienta. Niestety nie zostało to zaobserwowane w firmie XYZ. Budowanie i utrzymanie dobrych, mocnych kontaktów z klientami nie jest kluczowe dla firmy. Obniżane są standardy w celu uzyskania nowej umowy, co z punktu widzenia obsługi klienta musi być źle oceniane i niepożądane.

Kończąc rozważania na temat usług, trzeba zaznaczyć, że liczba przewozów traktowana jest jako najważniejszy czynnik, natomiast obsługa klienta jest sprawą drugorzędną. Nie ulega wątpliwości, że rynek potrzeb na usługi kurierskie z roku na rok rośnie, potencjał przewozowy jest wykorzystywany prawie w $100 \%$, wpływ na obsługę klienta prawdopodobnie nie zmieni się w najbliższej przyszłości, gdyż firma kurierska przyjmuje więcej zamówień, niż może w rzeczywistości zrealizować, co ma bezpośredni wpływ na poziom budowania relacji i obsługi klienta.

Konkurowanie jakością na obecnym rynku usług kurierskich może spowodować znaczne podwyższenie kosztów i straty związane z dużą liczbą przewożonych przesyłek, a w analizowanej firmie podejście do obsługi klienta i budowanie relacji wykazuje znaczne braki w zakresie profesjonalizmu wymaganego w tej branży.

\section{Systemy informatyczne}

Istotną częścią nadzorowania i śledzenia nadanej paczki jest zastosowanie odpowiedniego systemu informatycznego. Czas i właściwe miejsce dostarczenia przesyłki ma wpływ na zwiększenie efektywności firmy kurierskiej. Kluczowym czynnikiem w transferze przesyłek jest umiejętność zarządzania informacją, a do tego są niezbędne narzędzia z dziedziny informatyki. Specyfika realizacji zamówień w firmie kurierskiej i obsługa zamówienia różnią się od działalności standardowych magazynów, gdzie towar niebędący przesyłką kurierską można zdefiniować lub określić pod względem jego złożoności, co daje możliwość przypisania go do danej działalności gospodarczej. Inaczej wygląda sprawa w przypadku działalności kurierskiej, gdzie przesyłki trafiają do sortowni bądź magazynów i czas dostarczenia przesyłki musi być zredukowany do minimum. Ponieważ możemy mieć do czynienia z klientami sklepów internetowych, którzy dokonują w większości przypadków transakcji jednorazowych lub w znacznych odstępach czasowych, niemożliwe jest trafne zdefiniowanie preferencji klienta w perspektywie długoterminowej współpracy.

Biorąc pod uwagę wszystkie te czynniki, potrzebne jest zastosowanie funkcjonalnych systemów informatycznych, służących do nadzorowania przepływu informacji 
w firmie, ale również udostępniania informacji klientowi. Użycie odpowiedniego narzędzia informatycznego wiąże się z określeniem jego cech, zdefiniowaniem zadań, jakie ma zrealizować, oraz tego, w jakich obszarach praca człowieka może być zastąpiona przez system informatyczny albo dzięki niemu uproszczona. Po ustaleniu tych kwestii firma może zacząć wdrażać system, co jest dosyć skomplikowanym procesem, ale przy odpowiednim doborze przynosi firmie kurierskiej wymierne korzyści. Zatem najistotniejszym elementem w nadzorze nad przesyłkami jest dokładne zdefiniowanie, co system ma nadzorować i jak ma wspomagać działalność firmy. Jego głównym zadaniem jest śledzenie przesyłek, ale również zbieranie i umiejętne wykorzystanie informacji o nadawcach i odbiorcach, usprawnienia działań wewnętrznych, zarówno w sortowniach, jak i magazynach, automatyczna identyfikacja przesyłki. Zewnętrzna firma wdrażająca taki system musi uwzględnić wszystkie te czynniki, a funkcjonalność systemu musi iść w parze z rozwojem firmy, czyli wraz z nowo pojawiającymi się obszarami system powinien być rozszerzany o kolejne możliwości, wspierające pracowników. Takie działanie wpłynie na wzrost poziomu obsługi klienta.

\section{Jakość usług kurierskich}

Pomiar jakości oferty firmy można wykonać różnymi metodami, opisanymi w literaturze przedmiotu. Mają one za zadanie uzyskanie informacji o zadowoleniu klienta oraz osiągniętym celu. Ukazują również obszary działalności, które nie przynoszą założonych efektów oraz dają możliwość porównania ich z ofertami firm konkurencyjnych. Na podstawie analiz danych można nanieść poprawki w obszarach działających niepoprawnie.

Mierniki i wskaźniki w logistyce traktowane są jako wielkości informacyjne wyrażone w jednostkach bezwzględnych, niesłużące do ocen, tylko do pomiaru zdarzeń logistycznych. Odzwierciedlają one stan rzeczywisty procesów i systemów logistycznych, dostarczają informacji z zakresu przepływu towarów oraz danych dotyczących miejsca, czasu i jakości. Obsługa klienta jest jednym z obszarów, gdzie można użyć mierników i wskaźników do uzyskania odpowiedzi na ważne pytanie związane z ich obsługą.

Wszystkie dane do pomiarów zostały zebrane podczas obserwacji realizacji zleceń w firmie XYZ. Dane były rejestrowane na bieżąco i na ich podstawie dokonano obliczeń wydajności firmy XYZ.

Wysokie zadowolenie klienta jest sukcesem firmy, aby je zmierzyć, można zbadać odczucia klienta poprzez przeprowadzanie ankiet bądź wywiadów. Głównymi kryteriami wyboru firmy przez klienta są:

- jakość produktu,

- poziom obsługi,

- obraz dostawcy, 
- obsługa sprzedaży,

- cena,

- niezawodność,

- kompletność dostawy,

- możliwość skracania cyklu dostaw,

- rozwój kontaktów osobistych i inne związane z tym problemy.

Dla powyższych kryteriów istotną sprawą jest współpraca pomiędzy dostawcami i klientami, które określa się na podstawie analizy kosztów całkowitych z punktu widzenia skutków ekonomicznych. Dane zostały zarejestrowane za okres 8.10.201814.10.2018. Średnio na każdego kuriera przypadało około 45 przesyłek dziennie, w dostarczaniu przesyłek uczestniczyło 6 samochodów dostawczych. Ogólna liczba kurierów wynosiła około 20 osób. W niniejszej analizie wzięto pod uwagę ograniczoną liczbę kurierów i na podstawie ich pracy uzyskano dane o wydajności firmy.

W tabeli 2 zostały zawarte wszystkie transakcje ogółem, włączając te zrealizowane, jak i niezrealizowane. Na podstawie tych danych dokonano obliczeń i uzyskano procentową wartość wszystkich mierników wydajności firmy.

Tabela 2. Transakcje zrealizowane i niezrealizowane

\begin{tabular}{|l|c|}
\hline Liczba zamówień otrzy171manych & 1912 \\
\hline Liczba zamówień przyjętych do realizacji & 1890 \\
\hline Liczba zamówień zrealizowanych & 1878 \\
\hline Liczba zamówień zrealizowanych w terminie & 48 \\
\hline Liczba zamówień nieterminowych & 1890 \\
\hline Liczba dokumentów wystawionych ogółem & 12 \\
\hline Liczba dokumentów zwróconych & 12 \\
\hline Liczba dostaw reklamowanych & 12 \\
\hline Liczba dostaw nieprawidłowych & 12 \\
\hline Liczba zwróconych dostaw & 1890 \\
\hline Ogólna liczba faktur & 35 \\
\hline Liczba błędnych faktur & 1890 \\
\hline Liczba opracowanych zamówień & 1842 \\
\hline Liczba terminowo opracowanych zamówień & 12 \\
\hline
\end{tabular}

Źródło: opracowanie własne na podstawie dokumentacji firmy XYZ.

Poniżej przedstawione zostaną wyliczenia obrazujące jakość obsługi klienta w firmie XYZ. Każdy z uzyskanych wyników został odpowiednio skomentowany. 
Równanie 1. Udział zamówień przyjętych do realizacji

$$
\begin{gathered}
\frac{\text { liczba zamówień przyjętych do realizacji }}{\text { łączna liczba zamówień otrzymanych }} * 100 \% \\
\frac{1890}{1912} * 100 \%=98,84 \% \text {. }
\end{gathered}
$$

Firma zastrzega sobie niezrealizowanie zamówień, które nie spełniają warunków umowy zawartej podczas przyjęcia zlecenia. W trakcie obserwacji autora okazało się, że kilku klientów próbowało wysłać przesyłkę niezgodną z deklaracją złożoną przy zamówieniu kuriera, na przykład zamierzano wysłać żywe zwierzę, cenne rzeczy czy przesyłkę ponadwymiarową. Firma nie podjęła się wykonania zlecenia, zastrzegając sobie taką możliwość, o czym poinformowała klienta.

Równanie 2. Wskaźnik realizacji dostaw

$$
\begin{gathered}
\frac{\text { liczba zamówień zrealizowanych }}{\text { liczba zamówień przyjętych }} * 100 \% \\
\frac{1878}{1890} * 100 \%=99,36 \% .
\end{gathered}
$$

Wskaźnik przedstawiony wyżej wykazał, że efektywność firmy jest bardzo wysoka. Prawie 100\% złożonych zamówień zostało przyjętych do realizacji, a tylko 12 zostało odrzuconych.

Równanie 3. Terminowość i pewność realizowanych zamówień

Terminowość kuriera jest zależna od dostępności usługi dla konkretnego miasta. Najszybszym dostarczeniem przesyłki do klienta charakteryzowały się te przesyłki, które znajdowały się w obrębie miejsca, gdzie znajduje się oddział firmy. Największym wyzwaniem były przesyłki z poranną godziną doręczenia, zwłaszcza że zależało to od transportu głównej sortowni dostarczającego przesyłki do łódzkiego oddziału.

Wynik terminowości dostarczania zamówień:

$$
\begin{gathered}
\frac{\text { zamówienia zrealizowane w żądanym terminie }}{\text { łączna liczba przyjętych zamówień }} * 100 \% \\
\frac{1842}{1890} * 100 \%=97,46 \% .
\end{gathered}
$$

Ze względu na odległość do przebycia pomiędzy oddziałami oraz wypadki losowe zdarzały się opóźnienia powodujące niewywiązanie się z terminowości dostarczenia przesyłki. Trzeba do tego jeszcze dodać procesy rozładunku, sortowania i ponownego załadunku. Niemniej jednak terminowość całości zamówień wahała się w granicach około 98\%, co można uznać za wynik zadowalający. 
Równanie 4. Udział zamówień w niepełnym wymiarze

Opóźnienia spowodowanie różnymi czynnikami stanowiły 2,53\% wszystkich przyjętych zamówień. Wskaźnik ten potwierdza wysoką wydajność firmy. Wyliczenia przedstawione są poniżej:

$$
\begin{gathered}
\frac{\text { liczba zamówień zrealizowanych w niepełnym wymiarze }}{\text { łączna liczba zamówień przyjętych }} * 100 \% \\
\frac{48}{1890} * 100 \%=2,53 \% .
\end{gathered}
$$

Równanie 5. Wskaźnik reklamacji dostaw

$$
\begin{gathered}
\frac{\text { liczba dostaw reklamowanych }}{\text { ogólna liczba dostaw }} * 100 \% \\
\frac{12}{1890} * 100 \%=0,63 \%
\end{gathered}
$$

Z całej sumy ogólnej liczby dostaw wynoszącej 1890 tylko 12 było reklamowanych. Najczęstszą przyczynę reklamacji stanowiły uszkodzenia przesyłki i nieodpowiednie zabezpieczenie jej podczas transportu. Wszystkie reklamacje zostały uznane jako słuszne i odbiorca otrzymywał rekompensatę zgodną z umową zawartą z kurierem. Dokumentacja wadliwych przesyłek była również zwracana i jej udział w całym procesie wyniósł tyle samo, co udział przesyłek reklamowanych, czyli 0,63\%.

Równanie 6. Udział zwróconych dokumentów

$$
\begin{gathered}
\frac{\text { liczba dokumentów zwróconych }}{\text { liczba dokumentów wystawionych ogółem }} * 100 \% \\
\frac{12}{1890} * 100 \%=0,63 \% \text {. }
\end{gathered}
$$

Równanie 7. Wskaźnik nieprawidłowości dostaw

$$
\begin{gathered}
\frac{\text { liczba dostaw nieprawidłowych }}{\text { łączna liczba dostaw }} * 100 \% \\
\frac{12}{1890} * 100 \%=0,63 \%
\end{gathered}
$$

Równanie 8. Wskaźnik zwrotu dostaw

$$
\begin{gathered}
\frac{\text { liczba zwróconych dostaw }}{\text { łączna liczba dostaw }} * 100 \% \\
\frac{12}{1890} * 100 \%=0,63 \%
\end{gathered}
$$


Równanie 9. Wskaźnik bezbłędności faktur

Błędy zawarte w dokumentacji stanowiły 1,85\% wszystkich zamówień. Wszystkie niejasności były rozwiązywane na bieżąco przez kontakt telefoniczny z obsługą klienta.

$$
\begin{gathered}
\frac{\text { liczba błędnych faktur }}{\text { ogólna liczba faktur }} * 100 \% \\
\frac{35}{1890} * 100 \%=1,85 \%
\end{gathered}
$$

Równanie 10. Wskaźniki terminowo opracowanych zamówień

$$
\begin{gathered}
\frac{\text { liczba terminowo opracowanych zamówień }}{\text { łączna liczba opracowanych zamówień }} * 100 \% \\
\frac{1842}{1890} * 100 \%=97,46 \%
\end{gathered}
$$

Cały proces realizacji zamówienia, począwszy od przyjęcia, jest kluczowym procesem w ocenie obsługi klienta przez przedsiębiorstwo. Pomimo wielu niedociągnięć i uchybień w obsłudze klienta wynik 97,46\% terminowo opracowanych zamówień jest wynikiem bardzo dobrym.

\section{Zakończenie i najważniejsze wnioski}

Wybierając do analizy firmę kurierską, kierowano się dynamicznym rozwojem tej branży. Obsługa klienta jest jednym z kluczowych zagadnień prowadzenia firmy w branży kurierskiej i decyduje o jej pozycji na rynku.

W czasach ogromnej konkurencji i rywalizacji w zdobyciu klienta budowanie długofalowych relacji z klientem może mieć wpływ na późniejszy sukces bądź porażkę firmy na rynku. Dodatkowo w przypadku usług stosunek do klienta stanowi element budowania wizerunku oferowanego dobra, które w przeciwieństwie do produktu nie może być wcześniej ocenione co do jakości i zasad funkcjonowania. Firmy kurierskie muszą dostosować się do zmian realiów gospodarczych, odnosi się to do jakości podejścia do obsługi klienta oraz skutecznego realizowania zleceń, a nowe rozwiązania w wielu przypadkach nie są akceptowalne ani zrozumiałe dla nich samych.

Uważa się, że czas stabilizacji i zagospodarowania rynku spowoduje, że jakość obsługi klienta stanie się decydującym czynnikiem w wyborze firmy kurierskiej.

Oddział firmy XYZ, który był przedmiotem badań, chociaż jest już dosyć popularną marką na rynku usług kurierskich, to nie skupia się na niepodzielnej polityce prezentacji firmy, co skutkuje pogorszeniem postrzegania przedsiębiorstwa na rynku, ale nie jest to podejście prezentowane wyłącznie przez firmę XYZ. Podobne praktyki da się zauważyć w innych firmach tej branży. 
W przypadku nasycenia daną usługą firmy prezentują wysoki poziom podejścia do klienta, ponieważ jest to jeden z ważniejszych czynników uzyskania pozycji lidera w danej branży. Regulacje w firmie XYZ nie są spójne na różnych poziomach, a polityka poszczególnych działów często prowadzi do konfliktu interesów, co w wyniku analizy uznano za wadę w działalności firmy.

Autorzy swoją ocenę argumentują tym, że nie ma spójnych procedur związanych z obsługą. Brakuje także określonych zasad obsługi i przekazywania informacji o problemach klienta. Niewykluczone, że przy nasyceniu rynku firmami z tej samej branży ocena może ulec zmianie.

Na podstawie badania firmy XYZ można sformułować następujące wnioski:

1. Firma XYZ charakteryzuje się dużą wydajnością, co potwierdzają badania przeprowadzone za pomocą wskaźników.

2. Firma XYZ działa efektywnie, co również potwierdziły wyniki badań opartych na wskaźnikach.

3. Jakość usług kurierskich oceniana jest przez klientów pozytywnie.

4. Klienci twierdzą, że usługi kurierskie mają wysoką jakość.

5. Klienci bardzo często korzystają z usług firm kurierskich.

6. Najistotniejszym czynnikiem wyboru firmy kurierskiej według klientów jest cena oferowanych usług, a jej obniżenie spowodowałoby dodatkowy czynnik poprawiający jakość tychże usług.

7. Według klientów terminowość jest niezwykle ważnym czynnikiem w określaniu jakości usług firm kurierskich.

8. Klienci uznali, iż najważniejszym czynnikiem, który decyduje o reklamacji usług firm kurierskich, są uszkodzenia przesyłek.

\section{Bibliografia}

Arkit A. (2020), Analiza i ocena obstugi klienta $w$ firmie kurierskiej XYZ, praca dyplomowa, maszynopis niepublikowany, Wydział Techniki i Informatyki Akademii Humanistyczno-Ekonomicznej w Łodzi, Łódź.

Boguszewicz-Kreft M. (2005), Marketing ustug, [w:] W. Żurawik (red.), Marketingpodstawy i kontrowersje, Wydawnictwo Uniwersytetu Gdańskiego, Gdańsk 2005.

Dembińska-Cyran I. (2004), System obstugi klienta jako podstawa tworzenia i zarządzania relacjami z klientem, [w:] I. Dembińska-Cyran, J. Hołub-Iwan, J. Perenc (red.), Zarządzanie relacjami z klientem, Wydawnictwo Difin, Warszawa.

PWC (2019), Perspektywy wzrostu rynku przesylek kurierskich, ekspresowych i paczkowych (KEP) w Polsce do 2018 r. 
Styś A. (red.) (2001), Zarządzanie marketingowe w sferze ustug, Wydawnictwo Akademii Ekonomicznej, Wrocław.

\section{Summary \\ Analysis and evaluation of customer service in the courier company XYZ}

Logistic customer service is one of the most important tools for building a company's competitiveness on the market. This study assessed the effectiveness of XYZ customer service and focused mainly on the timeliness of ongoing services and the number of complaints. Characteristics of the courier industry in Poland, assessment of cooperation with Polish TSL companies and research results have shown the impact of the industry on the Polish company XYZ. Data collected while working at $X Y Z$ helped answer questions about logistic customer service indicators and timeliness of services. The data and indicators presented are based on information obtained while working at the company and collecting statistical data.

Keywords: courier service, customer service, quality of service 